\title{
STUDI LITERATUR TENTANG RISET ZAKAT
}

\author{
Aam Slamet Rusydiana \& Salman Al-Farisi \\ Sharia Economic Applied Research \& Training (SMART) Consulting \\ Perum Mutiara Bogor Raya Blok G4 No.3 \\ Katulampa, Bogor, Jawa Barat \\ E-mail: aamsmart@gmail.com
}

\begin{abstract}
Literature Study on Zakah Research. Zakah is not only as religious rituality but also could touch humanity aspect by empowering its potency to maximize public wealth. The research related to zakah is still lacking compare to Islamic banking research. This study review on research around zakah. The study use descriptive statistical analysis based on 100 journal publications related to zakah, both national and international journal. The entire sample journal publications have published last 5 years from 2011 to 2015. Results show that the zakah research is still dominated by the discussion of zakah institution (26\%), followed by distribution of zakah(22\%), zakah management $(21 \%)$ and poverty $(20 \%)$. The last theme is about zakah collection (11\%). In addition, comparison of quantitative research and mixed methods are still far less than the qualitative approach.
\end{abstract}

Keywords: Zakah Literatures, Zakah Issue, Research on Zakah

\begin{abstract}
Abstrak. Studi Literatur tentang Riset Zakat. Zakat tidak hanya sebagai ritual keagamaan tetapi juga bisa menyentuh aspek kemanusiaan dengan memberdayakan potensinya untuk memaksimalkan kekayaan publik. Penelitian yang berkaitan dengan zakat masih kurang jika dibandingkan dengan penelitian perbankan syariah. Penelitian ini mengkaji penelitian-penelitian tentang zakat. Penelitian ini menggunakan analisis statistik deskriptif berdasarkan 100 publikasi jurnal yang berkaitan dengan zakat, baik jurnal nasional maupun internasional. Sampel diambil dari jurnal yang terbit 5 tahun terakhir dari 2011 hingga 2015. Hasil penelitian menunjukkan bahwa penelitian zakat masih didominasi oleh pembahasan lembaga zakat (26\%), diikuti oleh distribusi zakat (22\%), manajemen zakat (21\%) dan kemiskinan (20\%). Tema terakhir adalah tentang koleksi zakat (11\%). Selain itu, perbandingan antara penelitian kuantitatif dan metode gabungan masih jauh lebih sedikit dibandingkan dengan pendekatan kualitatif.
\end{abstract}

Kata Kunci: Literatur Zakat, Isu Zakat, Penelitian Zakat

\section{Pendahuluan}

Zakat sebagai salah satu rukun Islam mempunyai ciri khas yang berbeda karena ia tidak hanya berdimensi vertikal seperti rukun Islam lainnya-yaitu hubungan ibadah kepada Allah Swt.- tetapi juga berdimensi horizontal yaitu hubungan ibadah terhadap sesama manusia. Dimensi horizontal ini mempunyai efek yang luas sehingga secara sosial diharapkan dapat membangun masyarakat madani atas dasar silaturahmi dan secara ekonomi, menurut Mustaq Ahmad, adalah sumber utama kas negara dan sekaligus merupakan sokoguru dari kehidupan ekonomi yang dicanangkan Alquran.

Zakat merupakan injeksi dalam perekonomian sehingga memunculkan kekuatan baru dalam penghimpunan investasi yang signifikan sehingga akan

Naskah diterima: 8 November 2015; Direvisi: 2 Juni 2016; Disetujui untuk diterbitkan: 10 Juni 2016. mendorong peningkatan produksi dalam siklus perekonomian suatu daerah. Bahkan secara makro zakat akan dapat meningkatkan agregat demand karena meningkatnya purchasing power (daya beli) masyarakat atas barang-barang dan jasa. Ketika zakat diiplementasikan secara tersistem, dalam artian bahwa zakat adalah peraturan yang mengikat dalam diri setiap Muslim dengan peran pemerintah sebagai regulator sekaligus badan amil zakatnya, maka secara pasti akan menyebabkan munculnya lapangan-lapangan kerja baru yang sangat luas sehingga setiap warga negara mempunyai lahan pekerjaan dan otomatis akan terjadi migrasi pengangguran menjadi karyawan dalam jumlah yang sangat besar.

Zakat juga berperan penting dalam mewujudkan terciptanya keadilan dalam bidang ekonomi dimana seluruh anggota warga negara mempunyai sumber pendapatan dan income untuk memenuhi kebutuhan sehari-hari dalam rangka menjalankan roda kehidupan 
di muka bumi ini. Oleh karena itu diperlukan lapangan pekerjaan yang cukup sebagai sumber atau ladang pendapatan yang halal. Dengan zakat maka akan terkumpul dana baru (fresh capital) yang bebas dari tekanan-tekanan apapun karena memang bersifat sukarela dan merupakan hak para kaum miskin.

Saat ini institusi zakat tidak hanya sebagai ritualitas keagamaan tetapi bisa menyentuh aspek kemanusiaan dengan memberdayakan potensinya untuk kesejahteraan publik semaksimal mungkin. Namun di sisi lain, riset dan pengembangan terkait zakat dan pengelolaannya masih sangat kurang, padahal hal ini sangat penting dilakukan.

Berdasarkan latar belakang yang dijelaskan di atas maka perumusan masalah dalam penelitian ini adalah: (1) Apa saja area kajian tentang zakat dan berapa persentasenya?; (2) Secara pendekatan metodologi penelitian, bagaimana komposisi riset terkait zakat secara umum? dan (3) Bagaimana persentase jumlah publikasi, tipe riset, pendekatan penelitian, subjek bahasan hingga area studi tentang zakat selama 5 tahun terakhir?

\section{Fokus Kajian}

Kajian dalam penelitian ini memfokuskan pada eksplorasi terhadap 100 penelitian up to date terkait zakat yang telah terpublikasi dalam jurnal ilmiah. Ada beberapa isu yang hendak diketahui jawabannya, yaitu berapa persentase riset terkait zakat selama 5 tahun terakhir, bagaimana jenis/tipe penelitian zakat dan komposisinya, bagaimana pendekatan penelitian tentang zakat dikaitkan dengan penggunaan metode penelitian baik kuantitatif, kualitatif maupun mixed.

Beberapa riset yang menjadikan Malaysia sebagai objek studi dilakukan oleh Hanapi (2015), Johari (2015) dan Said (2014) dan beberapa riset yang lainnya. Sementara itu riset yang lain menjadikan Indonesia sebagai objek kajian seperti yang dilakukan oleh Huda (2014) dan Rusli (2013). Negara lain juga menjadi area studi dalam penelitian zakat yang penulis telaah.

Selain yang tersebut di atas, fokus kajian juga mencoba menelaah lebih dalam terkait apa saja metode penelitian kuantitatif yang dipakai dan apa yang dominan dipakai. Bagaimana pula subjek pembahasan tentang zakat dan komposisinya. Tidak kalah penting, negara mana saja yang menjadi area studi dan area publikasi tentang riset zakat di seluruh dunia.

Penelitian ini menggunakan analisis statistika deskriptif berdasarkan 100 publikasi jurnal terkait zakat, baik nasional maupun internasional. Seluruh sampel publikasi jurnal yang telah terpublikasi 5 tahun terakhir mulai tahun 2011 hingga 2015. Studi hanya memfokuskan secara spesifik terhadap tulisan jurnal bertema zakat.

Selanjutnya, setelah dilakukan review dan analisis, penelitian terkait zakat ini dibagi ke dalam 5 (lima) kategori utama yaitu (1) Manajemen zakat, (2) Distribusi dana zakat, (3) Zakat dan kemiskinan, (4) Institusional zakat, dan (5) Pengumpulan (koleksi) dana zakat. Termasuk ke dalam term institusional adalah kelembagaan, payung hukum dan regulasi tentang zakat. Pengklasifikasian ini dibuat berdasarkan penelaahan isi, abstraksi dan keseluruhan penelitian secara umum, meskipun tidak menutup kemungkinan terjadinya irisan-irisan kategori dan klasifikasi.

\section{Jumlah Publikasi Setiap Tahun}

Pada bagian ini menjelaskan jumlah publikasi jurnal dari tahun 2011 hingga 2015. Terdapat 100 jurnal yang terpublikasi baik jurnal nasional maupun internasional yang berhubungan dengan zakat dari observasi 5 tahun terakhir selama tahun 2011 hingga 2015. Tabel 1 menjelaskan distribusi jurnal per tahun yang menunjukkan jumlah jurnal terpublikasi bervariasi dari tahun 2011 hingga 2015 dengan range 11 hingga 28 jurnal dan publikasi jurnal terbanyak yaitu pada tahun 2014. Sedangkan publikasi jurnal yang lebih sedikit dibandingkan tahun lainnya yaitu pada tahun 2011.

Tabel 1. Jumlah Publikasi per Tahun

\begin{tabular}{ccc}
\hline Tahun Publikasi & Jumlah Artikel & Persentase \\
\hline 2011 & 11 & $11 \%$ \\
\hline 2012 & 21 & $21 \%$ \\
\hline 2013 & 18 & $18 \%$ \\
\hline 2014 & 28 & $28 \%$ \\
\hline 2015 & 22 & $22 \%$ \\
\hline Total & 100 & 1 \\
\hline
\end{tabular}

\section{Jenis Penelitian dari Masing-Masing Publikasi}

Tabel 2 menunjukkan jenis (tipe) penelitian yang digunakan untuk setiap publikasi jurnal yang diamati. Menurut Sekaran (2013), secara umum terdapat empat tipe penelitian yaitu analisis, deskriptif, empiris dan penelitian eksploratori. Dalam observasi ini hanya menggunakan tiga jenis tipe penelitian yaitu analisis, deskriptif dan empiris.

Penelitian analisis digunakan untuk mencoba menjawab persoalan mengapa hal tertentu atau bagaimana hal tersebut dapat terjadi. Jenis penelitian ini biasanya berhubungan dengan sebab akibat. Penelitian deskriptif 
mencoba untuk menentukan, menggambarkan atau mengidentifikasi hal tertentu. Penelitian deskriptif menggunakan deskripsi, klasifikasi, pengukuran dan perbandingan untuk menggambarkan suatu fenomena. Dan metode penelitian empiris yaitu metode penelitian yang menggunakan observasi studi lapangan (empiris) atau data yang terkumpul dari tanya jawab seperti dalam bentuk kuisioner.

Dari tabel 2 dapat diketahui bahwa jenis metodologi penelitian yang terbanyak digunakan dari jurnal terpublikasi baik jurnal nasional dan internasional terkait zakat selama tahun 2011 hingga 2015 yaitu metodologi penelitian deskriptif sejumlah 49 jurnal, kemudian diikuti oleh metodologi penelitian analisis sejumlah 39 jurnal dan terakhir yaitu jurnal yang menggunakan penelitian empiris sebanyak 12 jurnal.

Tabel 2. Jenis Penelitian dari Masing- Masing Publikasi

\begin{tabular}{ccccc}
\hline \multirow{2}{*}{$\begin{array}{c}\text { Year of } \\
\text { Publication }\end{array}$} & \multicolumn{3}{c}{ Research Types } & \multirow{2}{*}{ Total } \\
\cline { 2 - 4 } & Analytical & Descriptive & Empirical & \\
\hline 2011 & 4 & 7 & 0 & 11 \\
\hline 2012 & 4 & 14 & 3 & 21 \\
\hline 2013 & 6 & 9 & 3 & 18 \\
\hline 2014 & 14 & 12 & 2 & 28 \\
\hline 2015 & 11 & 7 & 4 & 22 \\
\hline Total & 39 & 49 & 12 & 100 \\
\hline
\end{tabular}

\section{Pendekatan Penelitian Masing- Masing Publikasi}

Berdasarkan Punch (2013), ada 3 jenis pendekatan penelitian yaitu pendekatan kualitatif, pendekatan kuantitatif dan pendekatan metodologi campuran (mixed method). Tabel 3 menunjukkan metodologi penelitian yang digunakan untuk setiap jurnal terpublikasi dalam kurun waktu 5 tahun yaitu 2011 hingga 2015. Dalam observasi ini, pendekatan penelitian yang terbanyak digunakan adalah pendekatan kualitatif sejumlah 61 jurnal, kemudian pendekatan kuantitatif sejumlah 37 jurnal dan terakhir yaitu jurnal yang menggunakan pendekatan kombinasi (mixed method) sejumlah 2 jurnal.

Tabel 3. Pendekatan Penelitian Masing- Masing Publikasi

\begin{tabular}{ccccc}
\hline \multirow{2}{*}{$\begin{array}{c}\text { Year of } \\
\text { Publication }\end{array}$} & \multicolumn{3}{c}{ Research Types } & \multirow{2}{*}{ Total } \\
\cline { 2 - 4 } & Qualitative & Quantitative & Mixed & \\
\hline 2011 & 7 & 4 & 0 & 11 \\
\hline 2012 & 17 & 4 & 0 & 21 \\
\hline 2013 & 12 & 6 & 0 & 18 \\
\hline 2014 & 14 & 13 & 1 & 28 \\
\hline 2015 & 11 & 10 & 1 & 22 \\
\hline Total & 61 & 37 & 2 & 100 \\
\hline
\end{tabular}

\section{Jenis Metodologi Kuantitatif}

Tabel 4 menunjukkan jenis- jenis metodologi penelitian kuantitatif yang digunakan dalam 100 jurnal publikasi terpilih. Adapun dalam 100 jurnal zakat terdapat 25 jenis metodologi penelitian kuantitatif yang digunakan, yaitu metode Multiple Regression Analysis (5), Structural Equation Modeling (4), Panel Data (4), VECM (3), AHP (3), DEA (2), Faktor Analisis (2), Rasch Measurement Model (2), PLS (2, dan metode lainnya (1).

Tabel. 4. Jenis Metodologi Penelitian Kuantitatif

\begin{tabular}{ll}
\hline Quantitative Method & Number \\
\hline Multiple Regression Analysis & 5 \\
\hline Structural Equation Modeling & 4 \\
\hline Panel Data & 4 \\
\hline Vector Error Correction Model & 3 \\
\hline AHP & 3 \\
\hline Data Envelopment Analysis & 2 \\
\hline Factor Analysis & 2 \\
\hline Rasch Measurement Model & 2 \\
\hline Partial Least Square & 2 \\
\hline Partial Least Square path Modeling & 1 \\
\hline Two Stage Data Envelopment Analysis & 1 \\
\hline Linear Regression Model & 1 \\
\hline Wilxocon Analysis & 1 \\
\hline Tobit Regression & 1 \\
\hline Malmquist Productivity Index & 1 \\
\hline ANP & 1 \\
\hline Polynomial Model & 1 \\
\hline Exponential Model & 1 \\
\hline Discrete Malthusian Growth Model & 1 \\
\hline Moderated Regression Analysis & 1 \\
\hline C4.5 Decision Tree algorithm & 1 \\
\hline CAST Method & 1 \\
\hline Quota Sampling & 1 \\
\hline Logistic Regression & \\
\hline & \\
\hline
\end{tabular}

\section{Subjek Jurnal Zakat}

Tabel 5 menunjukkan subjek pembahasan masingmasing jurnal terkait zakat berdasarkan publikasi jurnal zakat selama tahun 2011 hingga 2015. Adapun dalam observasi ini berdasarkan lima subjek yaitu terkait manajemen zakat, distribusi zakat, pengentasan kemiskinan dan pengumpulan zakat dan institusi zakat. Dari publikasi jurnal 2011-2015 terpilih dalam pengamatan, subjek pembahasan terkait jurnal zakat terbanyak yaitu mengenai institusi zakat sejumlah 26 jurnal dari 100 sampel jurnal, kemudian diikuti oleh subjek pembahasan mengenai distribusi zakat 
sejumlah 22 jurnal, manajemen zakat sejumlah 21 jurnal, pengentasan kemiskinan sejumlah 20 jurnal dan terakhir terkait pengumpulan zakat sejumlah 11 jurnal.

Tabel 5.Subjek Pembahasan Jurnal Zakat

\begin{tabular}{lcccccc}
\hline \multirow{2}{*}{$\begin{array}{c}\text { Subject of } \\
\text { Article }\end{array}$} & \multicolumn{5}{c}{ Year of Publication } & \multirow{2}{*}{ Total } \\
\cline { 2 - 6 } & 2011 & $\mathbf{2 0 1 2}$ & $\mathbf{2 0 1 3}$ & $\mathbf{2 0 1 4}$ & $\mathbf{2 0 1 5}$ & \\
\hline Management & 2 & 4 & 6 & 6 & 3 & 21 \\
\hline Distribution & 2 & 7 & 3 & 4 & 6 & 22 \\
\hline Poverty & 3 & 5 & 4 & 3 & 5 & 20 \\
\hline Collection & 1 & 0 & 3 & 4 & 3 & 11 \\
\hline Institution & 3 & 5 & 2 & 11 & 5 & 26 \\
\hline \multicolumn{1}{c}{ Total } & 11 & 21 & 18 & 28 & 22 & 100 \\
\hline
\end{tabular}

\section{Area Studi dan Publikasi Berdasarkan Negara}

Tabel 6 menunjukkan daftar terbanyak publikasi berdasarkan letak geografis (negara). Tabel ini dibagi menjadi 2 bagian yaitu lokasi studi 100 jurnal publikasi terpilih dan lokasi publikasi 100 jurnal tersebut. Pada bagian pertama, mengenai lokasi studi jurnal. Dari tabel 6 dapat diketahui bahwa Indonesia menjadi area studi terbanyak terkait penelitian zakat yaitu sejumlah (35 jurnal), diikuti oleh Negara Malaysia (34 jurnal), Nigeria (3 jurnal), Pakistan (3 jurnal) dan negaranegara lainnya ( 1 jurnal).

Senada dengan area studi, dari segi area publikasi jurnal, Indonesia menjadi negara yang terbanyak publikasi terkait penelitian zakat sejumlah (33 jurnal), USA (13 jurnal), Malaysia (9 jurnal), Timur Tengah (6 jurnal), Australia (3 jurnal), Pakistan (4 jurnal), Bangladesh (4 jurnal), Kanada (4 jurnal), UK (4 jurnal), India (3 jurnal), Australia (3 jurnal), Turki (2 jurnal) dan negara lainnya (1 jurnal).

Adapun area publikasi dari 100 jurnal zakat terpilih bervariasi yaitu terdapat 70 jenis jurnal. Dalam penelitian zakat ini, International Journal of Business and Social Science menjadi jurnal terbanyak dalam mempublikasikan jurnal terkait zakat yaitu sejumlah 8 jurnal, kemudian diikuti oleh Middle-East Journal of Scientific Research (5 jurnal), Journal of Islamic Economics, Banking and Finance (4 jurnal), Tazkia Islamic Finance and Business Review (4 jurnal), Jurnal BIMAS Islam (4 jurnal), International Journal of Economics, Management \& Accounting (3 jurnal), Jurnal Ekonomi dan Keuangan (3 jurnal), Economic: Jurnal Ekonomi dan Hukum Islam (3 jurnal), Journal of Economic Cooperation and Development (2 jurnal), Australian Journal of Basic and Applied Sciences (2 jurnal), Al- Iqtishad (2 jurnal), International Journal of Management and Commerce Innovations (2 jurnal) dan jurnal lainnya (1 jurnal).
Tabel 6.Area Studi dan Publikasi Berdasarkan Negara

\begin{tabular}{lcc}
\hline Country & Studied Area & Publication Area \\
\hline Indonesia & 35 & 33 \\
\hline Malaysia & 34 & 9 \\
\hline Nigeria & 3 & 0 \\
\hline Pakistan & 3 & 4 \\
\hline Bangladesh & 1 & 4 \\
\hline India & 0 & 3 \\
\hline Turki & 0 & 2 \\
\hline Timur Tengah & 0 & 6 \\
\hline USA & 0 & 13 \\
\hline UK & 0 & 4 \\
\hline Kanada & 0 & 4 \\
\hline Australia & 0 & 3 \\
\hline Lainnya & 6 & 15 \\
\hline TOTAL & 82 & 100 \\
\hline
\end{tabular}

\section{Temuan Penelitian}

Analisis 100 publikasi jurnal terkait studi zakat dari tahun 2011 hingga 2015 adalah (1) Terdapat keragaman pembahasan jurnal terkait zakat yang terpublikasi telah didiskusikan. Jumlah publikasi terbanyak yaitu pada tahun 2014 sebanyak 28 jurnal dari 100 sampel jurnal terpublikasi. (2) Umumnya penggunaan metode penelitian deskriptif untuk menjawab fenomena zakat di suatu negara tertentu masih mendominasi metode penelitiannya yaitu sejumlah (49 jurnal) dari 100 sampel jurnal. Sedangkan metode penelitian analisis (39 jurnal) dan metode penelitian empiris (12 jurnal). (3) Secara umum dari 100 publikasi jurnal menggunakan metode pendekatan kualitatif dalam membahas zakat sebanyak (61 jurnal), pendekatan kuantitatif (37 jurnal), pendekatan mixed method (2 jurnal). (4) Subjek pembahasan 100 publikasi jurnal zakat tersebut lebih banyak terkait institusi zakat itu sendiri, kemudian disusul terkait distribusi, manajemen, pengentasan kemiskinan dan pengumpulan dana zakat. (5) Negara Indonesia menjadi area studi zakat terbanyak dari 100 sampel publikasi jurnal tersebut dibandingkan negara lainnya. Disamping itu, jurnal- jurnal Indonesia menjadi terbanyak dalam publikasi jurnal tentang zakat.

Hasil dari analisis di atas dapat diketahui bahwa isu zakat menjadi pembahasan yang intensif oleh pakarpakar Muslim dari tahun ke tahun. Hal ini dibuktikan dengan dominasi publikasi jurnal 2 tahun terakhir yaitu 2014 dan 2015 yang lebih banyak dibandingkan dengan tahun sebelumnya terkait isu zakat. Selain itu, isu- isu tentang zakat lebih banyak dikaji atau dibahas dengan menggunakan metode deskriptif dan kualitatif. 
Subjek pembahasan yang terbanyak didiskusikan mengenai institusi zakat itu sendiri.

\section{Penutup}

Penelitian tentang zakat memiliki peran penting untuk umat Islam dalam menyadari kewajiban menunaikan zakat sebagai salah satu rukun Islam. Selain itu dapat meningkatkan kesadaran dari optimalisasi dana zakat dalam mengentaskan kemiskinan dan menyejahterakan masyarakat. Pembahasan penelitian zakat masih didominasi oleh pembahasan institusi zakat dari tahun 2011 hingga 2015. Sebab mayoritas penulis ratarata mengangkat isu terkait kelembagaan zakat yang berlandaskan payung hukum yang kuat sehingga dengan hal tersebut diduga dapat meningkatkan kesadaran dan kepercayaan masyarakat untuk membayar zakat yang kemudian akan dikelola serta disalurkan kepada pihak- pihak yang berhak menerimanya (ashnâf). Selain itu, perbandingan metode penelitian kuantitatif masih lebih sedikit dibandingkan dengan pendekatan kualitatif. Hal ini menjadi potensi untuk meningkatkan penelitian tentang zakat dengan menggunakan metode kuantitatif.[]

\section{Pustaka Acuan}

\section{1}

Abdullah, Muhammad and Suhaib, Abdul Quddus. (2011). "The Impact of Zakat on Social Life of Muslim Society". Pakistan Journal of Islamic Research Vol 8.

Abioye, Mustafa Murtala Oladimeji, Mohamad, Muslim Har Sani and Adnan, Muhammad Akhyar. (2011). "Antecedents of Zakat Payers Trust, the Case of Nigeria". International Journal of Economics, Management \& Accounting, Supplementary Issue 19: 133-164.

Adebayo, Dr. R. Ibrahim. (2011). "Zakat and Poverty Alleviation, a Lesson for the Fiscal Policy Makers in Nigeria”. Journal of Islamic Economics, Banking and Finance, Vol. 7 No. 4.

Azharsyah. (2011). "Maksimalisasi Zakat sebagai Salah Satu Komponen Fiskal dalam Sistem Ekonomi Islam”. Jurnal Syariah Vol. 3 No. 1.

Bakar, Mahyuddin Haji Abu and Ghani, Prof. Dr. Abdullah Haji Abd. (2011). "Towards Achieving the Quality of Life in the Management of Zakat Distribution to the Rifhtful Recipients". International Journal of Business and Social Science Vol. 2 No. 4.
Din, Hafiz Salah Ud and Atta Malik Amer. (2011). "The Role of Zakat in Establishment of a Model Society". Gomal University Journal of Research 27(1): 149-158.

Jumaizi and Wijaya, Zainal A. (2011). "Good Governance BAZIS dan Dampaknya thd Keputusan dan Loyalitas Muzaki”. Majalah Ilmiah Informatika Vol. 2 No. 3.

Mohsin, Magda Ismail A., Lahsasna, Ahcene, Ismail, Ezamshah. (2011). "Zakah from Salary and EPF, Issues and Challenges". International Journal of Business and Social Science Vol. 2 No. 1.

Shariff, Anita Md, Jusoh, Wan Noor Hazlina Wan, Mansor, Norudin and Jusoff, Kamaruzaman. (2011). "A Robust Zakah System, Towards a Progressive Socio-Economic Development in Malaysia". Middle-East Journal of Scientific Research 7 (4): 550554 ISSN 1990-9233.

Wiliasih, Ranti, Usman, Hardius, Marzuki, Khafid, Mardoni, and Yosi, Marcelo. (2011). "Relationship between Quality of Life and Reguler Zakah Exercise". International Journal of Business and Social Science Vol. 2 No. 16.

Yusoff, Mohammed B. (2011). "Zakat Expenditure, School Enrollment and Economic Growth in Malaysia”. International Journal of Business and Social Science Vol. 2 No. 6.

\section{2}

Abdullah, Luqman Haji, Ahmad, Wan Marhaini Wan, Rahman, Noor Naemah Abdul, Ali, Abdul Karim, Nor, Mohd Roslan Mohd, Khalil, Shahidra Abdul and Al-Nahari, Ameen Ahmed Abdullah Qasen. (2012). "Juristic Discourse on the Delay in Payment and Distribution of Zakat". Middle-East Journal of Scientific Research 12 (2): 176-181, ISSN 19909233.

Abdullah, Naziruddin, Yusop, Mohd Mahyudi Mohd, and Hj. Awang, Che Omar. (2012). "A Technical Note on the Derivation of Zakat Effectiveness Index (ZEIN)". International Journal of Economics, Management and Accounting Vol. 20, No.1: 75-86.

Ahmad, Wan Marhaini Wan and Mohamad, Shamsiah. (2012). "Classical Jurists View on the Allocation of Zakat, Is Zakat Investment Allowed". Middle-East Journal of Scientific Research 12 (2): 195-203, ISSN 1990-9233.

Awang, Rohila@Norhamizah and Mokhtar, Mohd Zulkifli. (2012). "Comparative Analysis of 
Current Values and Historical Cost in Business Zakat Assessment, an Evidence from Malaysia”. International Journal of Business and Social Science Vol. 3 No. 7.

Febianto, Irawan and Ashany, Arimbi Mardilla. (2012). "The Impact of Qardhul Hasan Financing using Zakah Funds on Economic Empowerment, Case Study DD West Java Indonesia”. Asian Business Review, Volume 1, Issue 1, ISSN 2304-2613.

Halim, Hazlina Abdul, Said, Jamaliah, Yusuf, Sharifah, Norzehan Syed. (2012). "Individual Characteristics of the Successful Asnaf Entrepreneurs, Opportunities and Solutions for Zakat Organisation in Malaysia”. International Business and Management Vol. 4, No. 2, 2012, pp. 41-49 ISSN 1923-8428.

Hendri, Davy. (2012). "ZIS Institutions and Inclusive Asset-building Policy Agenda”. Tazkia Islamic Finance and Business Review Volume 7.1.

Hummida, Dayang Binti Abang Abdul Rahman and Mohammed, Mustafa Omar. (2012). "The Role of Baitulmal towards the Education of Poor Muslims in Sarawak". Journal of Contemporary Issues and Thought Vol. 2.

Ibrahim, Abdullah, Abdullah, Abdul Aziz, Rizuan, Mohd Bin Abdul Kadir and Wafa, Syed Mohd Ghazali Syed AdwamWafa. (2012). "Assessing Financial Reporting on Adopting Business Zakat Guidelines on Malaysian Government Linked Companies". International Journal of Business and Social Science Vol. 3 No. 24.

Isnawati and Wirawan, Bintang. (2012). "Peranan Lazdai dalam Pengelolaan Dana Zakat untuk Bidang Pendidikan (Studi pada Lembaga Amil Zakat Amal Insani (LAZDAI) Lampung)". Jurnal Sociologie, Vol. 1, No. 4: 308-315.

Maerani, Ira Alia S.H. M.H. (2012). "Aplikasi Nilainilai Islam dalam Perda tentang Pengelolaan Zakat dan Problematikanya pada Era Otda di Kota Semarang”. Jurnal Hukum, Vol XXVIII, No. 2.

Mahalli, Amalia Kasyful. (2012). "Potensi dan Peranan Zakat dalam Mengentaskan Kemiskinan di Kota Medan”. Jurnal Ekonomi dan Keuangan, Vol. 1, No.1.

Nadzri, Farah Aida Ahmad, AbdRahman, Rashidah and Omar, Normah. (2012). "Zakat and Poverty Alleviation, Roles of Zakat Institutions in Malaysia”. International Journal of Arts and Commerce Vol. 1 No. 7.

Noor, Abd. Halim Mohd, Rasool, Mohamed Saladin
Abdul, Rahman, Rashidah Abdul, Yusof, Rozman Md and Ali, Siti Mariam. (2012). "Assessing Performance of Nonprofit Organization, A Framework for Zakat Institutions". British Journal of Economics, Finance and Management Sciences Vol. 5 (1).

Rahman, Azman Ab. (2012). "The Role of Zakat in Islamic Banking Institutions in Developing the Economy of the Poor and Needy in Malaysia". Tazkia Islamic Finance and Business Review Volume 7.2.

Rahman, Azman Ab, Alias, Mohammad Haji, Omar, Syed Mohd Najib Syed. (2012). "Zakat Institution in Malaysia, Problems and Issues". GJAT Journal Vol. 2 No. 1 ISSN: 2232-0474.

Sarea, Dr. Adel. (2012). "Zakat as a Benchmark to Evaluate Economic Growth, An Alternative Approach". International Journal of Business and Social Science Vol. 3 No. 18.

Siswantoro, Dodik. (2012). "The Need of Standardization of Individual Zakat Calculation in Indonesia". Tazkia Islamic Finance and Business Review Volume 7.1.

Tarar, Ayesha and Riaz, Madiha. (2012). "Impact of Zakat on Economy, Structure and Implementation in Pakistan". Journal of Economics and Sustainable Development ISSN 2222-1700 (Paper) ISSN 22222855 (Online) 2855 (Online) Vol. 3, No. 10.

Wahab, Norazlina Abd and Rahman, Abdul Rahim Abdul. (2012). "Efficiency of Zakat Institutions in Malaysia, an Application of DEA". Journal of Economic Cooperation and Development, 33, 1, 95112.

Yusoff, Mohammed B. and Densumite, Sorfina. (2012). "Zakat Distribution and Growth in the Federal Territory of Malaysia". Journal of Economics and Behavioral Studies Vol. 4, No. 8, pp. 449-456, ISSN: 2220-6140.

\section{3}

Ali, Ahmad Fahme Mohd, Noor, Zaleha binti Mohd, Aziz, Muhammad Ridhwan Ab, Ibrahim, Mohd Faisol, Johari, Fuadah. (2013). "Impact of Zakat Distribution on Poor and Need Recipients, an Analysis in Kelantan Malaysia”. Australian Journal of Basic and Applied Sciences, 7(13) Pages: 177-182.

Amuda, Yusuff Jelili. (2013). "Empowerment of Nigerian Muslim Households through Waqf Zakat Sadaqat and Public Funding". International Journal of Trade, Economics and Finance, Vol. 4, No. 6. 
Firmansyah, Irman and Aam S. Rusydiana. (2013). "Pengaruh Profitabilitas thd Pengeluaran Zakat pada BUS di Indonesia dengan Ukuran Perusahaan sebagai Variabel Moderasi”. Jurnal Liquidity Vol. 2 No. 2 Hlm. 110- 116.

Hermawan, Wawan. (2013). "Politik Hukum Zakat di Indonesia”. Jurnal Pendidikan Agama Islam - Tảlim Vol. 11 No. 2.

Hossain, Md. Ismail. (2013). "Analysis on Poverty Alleviation by Mosque Based Zakat Administration in Bangladesh, an Empirical Study". Journal of Poverty, Investment and Development Vol.1.

Htay, Sheila $\mathrm{Nu} \mathrm{Nu}$, Salman, Syed Ahmed, Ilyas, Soe Myint @ Haji. (2013). “Integrating Zakat Waqf and Sadaqah, Myint Myat Phu Zin Clinic Model in Myanmar". Tazkia Islamic Finance and Business Review Volume 8.2.

Huda, Nurul, Anggraini, Desti, Ali, Khalifah Muhamad, Rini, Nova, Mardoni, Yosi. (2013). "Komparasi AHP dan ANP dalam Penentuan Solusi Pengelolaan Zakat, (Kasus DKI dan SulSel)". Ekuitas: Jurnal Ekonomi dan Keuangan Volume 17, Nomor 3: 357 - 375 ISSN 1411-0393.

Istutik. (2013). "Analisis Implementasi Akuntansi Zakat dan Infak-Sedekah (PSAK 109) pada LAZ di Kota Malang”. Jurnal Akuntansi Aktual, Vol. 2, No. 1 hlm. 19-24.

Johari Fuadah, Aziz, Muhammad Ridhwan Ab, Ibrahim, Mohd Faisol and Ali, Ahmad Fahme Mohd. (2013). "The Roles of Islamic Social Welfare Assistant (Zakat) for the Economic Development of New Convert". Middle-East Journal of Scientific Research 18 (3): 330-339, ISSN 1990-9233.

Kholis, Nur, Sobaya, Soya, Andriansyah, Yuli, dan Iqbal, Muhammad. (2013). "Potret Filantropi Islam di Propinsi Daerah Istimewa Yogyakarta". La Riba Jurnal Ekonomi Islam Vol. VII, No. 1.

Mohsin, Magda Ismail A. (2013). "Potential of Zakat in Eliminating Riba and Eradicating Poverty in Muslim Countries \{Case Study: Salary Deduction Scheme of Malaysia”. EJBM-Special Issue:Islamic Management and Business Vol.5 No.11: ISSN 22221719.

Nadhari, Abdullah Khatib. (2013). "Pengelolaan Zakat di Dunia Muslim". Economic: Jurnal Ekonomi dan Hukum Islam, Vol. 3, No. 2 ISSN: 2088-6365.

Punch, Keith F. 2013. Introduction to Social Research: Quantitative and Qualitative Approaches. USA: Sage
Razak, Mohamad Idham Md, Omar, Assoc. Prof. Dr. Roaimah, Ismail, Maymunah, Hamzah, Afzan Sahilla Amir, Hashim, Assoc. Prof. Dr. Mohd Adnan. (2013). "Overview of Zakat Collection in Malaysia, Regional Analysis". American International Journal of Contemporary Research Vol. 3 No. 8.

Rusli, Hamzah, Abubakar, Syahnur, Sofyan. (2013). "Analisis Dampak Pemberian Modal Zakat Produktif thd Pengentasan Kemiskinan di Aceh Utara". Jurnal Ilmu Ekonomi Vol. 1 No. 1 pp. 56- 63 ISSN 23020172.

Sarea, Dr. Adel Mohammed. (2013). "Accounting Treatment of Zakah, Additional Evidence from AAOIFI". Journal of Islamic Banking and Finance, Vol. 1 No. 1.

Sari, Mutiara Dwi, Bahari, Zakaria, Hamat, Zahri. (2013). "Review on Indonesian Zakah Management and Obstacles". Social Sciences 2(2): pp. 76-89.

Sekaran, Uma. 2013. Research Methods for Business: A Skill-Building Approach, 6th Edition. USA: Wiley.

Suprayitno, Eko, Kader, Radiah Abdul, Harun, Azhar. (2013). "The Impact of Zakat on Aggregate Consumption in Malaysia". Journal of Islamic Economics, Banking and Finance, Vol. 9 No. 1.

Wahab, Norazlina Abd and Rahman, Abdul Rahim Abdul. (2013). "Determinants of Efficiency of Zakat Institutions in Malaysia, A Non-parametric Approach". Asian Journal of Business and Accounting 6(2), 2013 ISSN 1985-4064.

\section{4}

Ahmad, Ismail HJ and Ma'in Masturah. (2014). “The Efficiency of Zakat Collection and Distribution, Evidence from Two Stages Analysis". Journal of Economic Cooperation and Development, 35, 3 pp 133- 170.

Aji, Hastomo. (2014). "Intensi Muzakki Membayar Zakat Pendekatan Teori Planned Behaviour Modifikasi (Studi Terhadap Pegawai Kementerian Agama Pusat)". Jurnal Bimas Islam Vol.7. No.III.

Ali, Ahmad Fahme Mohd, and Aziz, Muhammad Ridhwan Ab. (2014). "Zakat Poverty Line Index and Gender Poverty in Malaysia: Some Issues and Practices". International Journal of Business and Social Science Vol. 5, No. 10.

Ali, Ahmad Fahme Mohd, Aziz, Muhammad Ridhwan $\mathrm{Ab}$, and Ibrahim, Mohd Faisol. (2014). "Zakat Poverty Line Index and Urban-Rural Poverty in 
Malaysia, a Critical Analysis". Pensee Journal Vol. 76, No. 7.

Ananda, David Bayu and Wibisono, Ari. (2014). "C4.5 Decision Tree Implementation in Sistem Informasi Zakat (SIZAKAT) to Automatically Determining the Amount of Zakat Received by Mustahik". Journal of Information Systems, Volume 10, Issue 1.

Gufroni, Acep Irham, Wisandani, Iwan and Sukmawati, Heni. (2014). "Sistem Informasi UPZ Terintegrasi Berbasis Web, Studi Kasus Baznas Kota Tasikmalaya”. Jurnal Sistem Komputer Vol. 4 No. 2, ISSN: 2087- 4685.

Gurning, Herfita Rizki Hasanah and Ritonga, Haroni Doli Hamoraon. (2014). "Analisis Tingkat Kesadaran Masyarakat Medan Baru dalam Membayar Zakat". Jurnal Ekonomi da Keuangan Vol.3 No.7.

Htay, Sheila Nu Nu and Salman, Syed Ahmed.(2014). "Proposed Best Practices of Financial Information Disclosure for Zakat Institution, a Case Study of Malaysia". World Applied Sciences Journal 30 (Innovation Challenges in Multidiciplinary Research \& Practice): 288-294, 2014, ISSN 1818-4952.

Huda, Nurul, Anggraini, Desti, Ali, Khalifah Muhamad, Mardoni, Yosi, and Rini, Nova. (2014). "Prioritas Solusi Permasalahan Pengelolaan Zakat dengan Metode AHP, Studi di Banten dan KalSel”. Al-Iqtishad: Vol. VI No. 2.

Huda, Nurul, Anggraini, Desti, Ali, Khalifah Muhamad, Rini, Nova, and Mardoni, Yosi. (2014). "Solutions to Indonesian Zakah Problems, AHP Approach". Journal of Islamic Economics, Banking and Finance, Vol. 10 No. 3.

Ibrahim, Ahmad Asad, Elatrash, Radwan Jamal, and Farooq, Mohammad Omar. (2014). "Hoarding versus Circulation of Wealth from the Perspective of Maqasid Shariah". International Journal of Islamic and Middle Eastern Finance and Management Vol. 7 No. 1 .

Johari, Fuadah, Ali, Ahmad Fahme Mohd, Aziz, Muhammad Ridhwan Ab and Ahmad, Nursilah. (2014). "The Importance of Zakat Distribution and Urban-Rural Poverty Incidence among Muallaf (New Convert)". Asian Social Science; Vol. 10, No. 21, ISSN 1911-2017.

Johari, Fuadah, Aziz, Muhammad Ridhwan Ab, Ali, Ahmad Fahme Mohd. (2014). "The Role of zakat in reducing poverty and income inequality among new convert in Selangor Malaysia”. Journal Research in Islamic Studies Vol. 1 No. 3, pp. 43- 56.
Johari, Fuadah, Aziz, Muhammad Ridhwan Ab., Ibrahim, Mohd Faisol, and Ali, Ahmad Fahme Mohd. (2014). "Zakat Distribution and Programme for Sustaining Muallaf Belief and Thought". Jurnal Teknologi (Social Sciences) 66:1, 35-43.

Khamis, Mohd Rahim, Mohd, Rohani, Salleh, Arifin Md, and Nawi, Abdol Samad. (2014). "Do Religious Practices Influence Compliance Behaviour of Business Zakat among SMEs". Journal of Emerging Economies and Islamic Research Vol. 2, No. 2.

Muhtada, D. (2014). "Islamic Philanthropy and the Third Sector, the Portrait of Zakat Organizations in Indonesia”. ISLAMIKA INDONESIANA, Vol. 1, Issue 1: 122-142.

Munif, Ahmad. (2014). "Zakat Madu Pada Masa Khalifah Umar Ibn Khattab RA. (Analisis Fiqhiyah dan Kebijakan Publik)". Jurnal Bimas Islam Vol.7. No.III.

Mustofa. (2014). "Sistem Ekonomi Keuangan Publik Berbasis Zakat". Jurnal Madani, Vol 4. No 1, ISSN: 2087-8761.

Noor, Abd Halim Mohd and Khairi, Nur Zehan.(2014). "What Determine Professionalism, a Study on Zakat Institutions Integration Efforts into the Mainstream Economy". Middle-East Journal of Scientific Research 22 (7): 983-993, ISSN 1990-9233.

Omar, W. A. Wan, Hussin, Fauzi and G. H. Asan Ali. (2014). "The Trend Analysis of Islamization in Malaysia using Islamization Index as Indicator". Asian Economic and Financial Review, 4(10): 12981313.

Rosmawati, Rosi. (2014). "Pengembangan Potensi Dana Zakat Produktif melalui LAZ untuk Meningkatkan Kesejahteraan Masyarakat”. Padjadjaran Jurnal Ilmu Hukum Vol. 1 No. 1.

Said, Jamaliah, Ahmad, Mahfuzah and Yusuf, Sharifah Norzehan Syed. (2014). "Effectiveness of Capital Assistance Program, Evidence from Malaysia". Research Journal of Applied Sciences, Engineering and Technology 8(4): 488-495, ISSN: 2040-7459.

Said, Hasani Ahmad. (2014). "Tafsir Ahkam: Zakat Sebagai Solusi Perekonomian Umat di Indonesia". Jurnal Bimas Islam Vol.7. No.III.

Salehi, Mahdi and Poour, Arash Ariyan. (2014). "A Study on the Influences of Islamic Values on Iranian Accounting Practice and Development". Journal of Islamic Economics, Banking and Finance, Vol. 10 No. 2.

Salleh, Muhammad Syukri. (2014). "Organizational 
and Definitional Reconfiguration of Zakat Management". International Journal of Education and Research Vol. 2 No. 5.

Siradj, Mustolih. (2014). "Long Road of Sharia Zakat Legislation in Indonesia: A study of Law No. 23 of 2011 about Zakat Management". Jurnal Bimas Islam Vol.7. No.III.

Yona, Rika Delfa. (2014). "Tarik Ulur Peran Pemerintah Dalam Pengelolaan Zakat”. Economic: Jurnal Ekonomi dan Hukum Islam, Vol. 4, No. 2, ISSN: 2088-6365.

Yusoff, Mohammed B. (2014). "Zakat distribution, education, and real income per capita in Malaysia". Review of Strategic and International Studies Vol. VI No. 3, ISSN: 2326-8085.

\section{5}

Almatar, Dr. Fatima. (2015). "Zakat vs Taxation the Issue of Social Justice and Redistribution of Wealth". European Journal of Business, Economics, and Accountancy Vol. 3 No. 3 ISSN 2056- 6018.

Fuadi, Thayeb, Dr. H. M. Hasballah, Suhaidi, Dr, and Kamello, Dr. Tan. (2015). "Conflict Setting between Zakat as a Deduction of Income Tax (Taxes Credit) and Zakat as Deduction of Taxable Income (Taxes Deductable), A Research in Aceh Indonesia". IOSR Journal of Economics and Finance (IOSR-JEF) e-ISSN: 2321-5933, p-ISSN: 2321-5925.Volume 6, Issue 2. Ver. I, PP 40-49.

Hanapi, Mohd Shukri. (2015). "Paddy Zakat Accounting and Its Relationship with the Social Wellbeing of Farmers, A Case Study in Perlis". Sains Humanika 4:2, 47-52.

Hasibuan, Khoiruddin. (2015). "Zakat and Its Effect to Community Empowerment, Case Studies DD Jogjakarta and Its Network". Jurnal Al- Ibrah Vol. 11 No. 1.

Hoque, Nazamul, Khan, Mohammad Aktaruzzaman and Mohammad, Kazi Deen. (2015). "Poverty Alleviation by Zakah in a Transitional Economy, A Small Business Entrepreneurial Framework". Journal of Global Entrepreneurship Research (5:7).

Huda, Nurul and Andriati, Rizky. (2015). "The Influences of Productive Zakah Mentoring to the Saving Behavior and the Prosperity of Poor Housewife". Al-Iqtishad: Vol. VII No. 2.

Hussain, Akhtar and Abdullah. (2015). "Importance of Zakat in the Establishment of the Society". GJRA - Global Journal for Research Analysis Volume-4,
Issue-4, ISSN No 2277 - 8160.

Ibrahim, Sheriff Muhammad. (2015). "Exploring the Motivational Factors for Corporate Zakat Payments". International Journal of Management and Commerce Innovations Vol. 3, Issue 1, pp: (429-436), ISSN 2348-7585.

Ibrahim, Sheriff Muhammad. (2015). "The Role of Zakat in Establishing Social Welfare and Economic Sustainability". International Journal of Management and Commerce Innovations, ISSN 2348-7585 (Online) Vol. 3, Issue 1, pp: (437-441).

Iqbal, Nadeem and Akhtar, Muhammad Ramzan. (2015). "Statistical Evaluation, Measuring and Managing Poverty in Rural Pakistan". Pakistan Journal of Statistics Vol. 31(6), 709-716.

Johari, Fuadah, Ali, Ahmad Fahme Mohd and Aziz, Muhammad Ridhwan AB. (2015). "The Role of Zakat Distribution among Muallaf in Reducing Poverty in Selangor Malaysia”. Journal of Economic Policy Researches Vol. 2, No. 1 (39-56).

Kahf, Monzer and Yafai, Samira Al. (2015). "Social Security and Zakah in Theory and Practice". International Journal of Economics, Management and Accounting 23, no. 2: 189-215.

Kantarci, Hasan Bulent. (2015). "The-Importance of Zakat in Struggle against Circle of Poverty and Income Redistribution". International Journal of Social, Behavioral, Educational, Economic, Business and Industrial Engineering Vol: 9, No: 1.

Kasri, Rahmatina and Ahmed, Habib. (2015). "Assessing Socio-Economic Development based on MS Principles, Normative Framework, Methods and Implementation in Indonesia”. Islamic Economic Studies Vol. 23, No. 1, (73-100).

Maghfiroh, Siti. (2015). "Model Manajemen Strategis Pemberdayaan Ekonomi Umat Melalui Zakat Infak Sedekah, Studi Kasus pada LAZIS Qaryah Thayyibah Purwokerto". Economic: Jurnal Ekonomi dan Hukum Islam, Vol.5, No. 2 ISSN: 2088-6365.

Mastura, Farah Binti Noor Azman and Zainol Bin Bidin. (2015). "Determinants of Attitude toward Zakat on Saving". Australian Journal of Basic and Applied Sciences, 9(31), Pages: 7-13 ISSN: 19918178.

Mastura, Farah Noor Azman and Zainol Bidin. (2015). "Factors Influencing Zakat Compliance Behavior on Saving". International Journal of Business and Social Research Volume 05, Issue 01.

Nurhayati, Sri and Siswantoro, Dodik. (2015). "Factors 
on Zakat Preference as a Tax Deduction in Aceh Indonesia". International Journal of Nusantara Islam, Vol.03 No.01; (1-20).

Othman, Azhana, Noor, Abdul Halim Mohd, Salleh, Arifin Md. (2015). "An Analysis Relationship between Social Exclusion and Non-Recipients Asnaf of Zakat Fund (NRAZF)". Australian Journal of Sustainable Business and Society Volume 1 No. 2.
Sarntisart, Saran. (2015). "The Economic Implications of Religious Giving”. I J A B E R, Vol. 13, No. 2, (2015): 687-716.

Syafei, Zakaria. (2015). "Public Trust of Zakat Management in the Office of Religious Affairs Serang Banten Indonesia". Journal of Management and Sustainability; Vol. 5, No. 3, ISSN 1925-4725 E-ISSN 1925-4733. 